$0.012 \sim 0.132, \quad P=0.018)$ and trunk $B F \% \quad(\beta=0.152,95 \% \mathrm{Cl} 0.043 \sim 0.261$, $P=0.007$ ), but not limb BF\%, were positively correlated with sUA.

\begin{tabular}{|c|c|c|c|c|c|c|c|}
\hline \multicolumn{8}{|c|}{ Figure 1 Clinical characteristics and body composition of gout patients } \\
\hline \multirow[b]{2}{*}{ characteristics } & \multirow{2}{*}{$\begin{array}{c}\text { All patients } \\
(n=362)\end{array}$} & \multicolumn{3}{|c|}{ Grouped by gender } & \multicolumn{3}{|c|}{ Male patients grouped by overfat } \\
\hline & & $\begin{array}{c}\text { Malo } \\
(n=348)\end{array}$ & $\begin{array}{c}\text { Fomale } \\
(n=14)\end{array}$ & P & $\begin{array}{l}\text { Ovorfat } \\
(n=187)\end{array}$ & $\begin{array}{c}\text { Non-ovorfat } \\
{[n=161)}\end{array}$ & $\mathbf{p}$ \\
\hline Age, years & $38(30,52)$ & $38(30,50)$ & $66(59,72)$ & $<0.001$ & $38(30,51)$ & $37(30,50)$ & 0.969 \\
\hline Duration, vears & $3(2,7)$ & $3(2,7)$ & $3(1,6)$ & 0.423 & $4(2,7)$ & $3(1,6)$ & 0.163 \\
\hline Count of affecting joints & $3(2,6)$ & $3(2,6)$ & $3(1,5)$ & 0.494 & $4(2,6)$ & $2(2,5)$ & 0.002 \\
\hline Family history, n(\%) & 130(35.9) & 124(35.6) & 6(42.9) & 0.581 & 74(39.6) & 50(31.1] & 0.098 \\
\hline Tophi, n(s) & 65(18.0) & 64(18.4) & 17.1.1) & 0.472 & 36(19.3) & $28(17.4)$ & 0.655 \\
\hline Serum uric acid , mg/dl & $9.2 \pm 2.2$ & $9.2 \pm 2.2$ & $9.2+2.5$ & 0.957 & $9.6 \pm 2.1$ & $8.7 \pm 2.2$ & $<0.001$ \\
\hline eGFR, $\mathrm{ml} / \mathrm{min}-1 / 1.73 \mathrm{~m}-2$ & 83.8t77.0 & $84.3+16.9$ & 70.4111.7. & 0.002 & 85.1418.2 & 83.5t15.3 & 0.395 \\
\hline Urolithiasis, $n(\%)$ & 83(24.3) & $85[2.44)$ & $3(21.4)$ & 0.795 & $49(2.2)$ & $36(22.4)$ & 0.405 \\
\hline Hypertension, $n$ (\%) & $133(36.7)$ & 122(35.6) & $9(64.3)$ & 0.029 & $83(44.4)$ & $41(25.5)$ & $<0.001$ \\
\hline Dibbotes mellitus, $n(\%)$ & $36(9.9)$ & $33(9.5)$ & $3(21.4)$ & 0.313 & 23(12.3) & ${ }^{10}(6.2)$ & 0.053 \\
\hline Dyslipiddemia, $n(5 \%)$ & $2286(63.0)$ & $218(62.6)$ & 10(71.4) & 0.504 & 131(70.1) & $87(54.0)$ & 0.002 \\
\hline Body mass index, kg/m2 & 25.533 .6 & 25.553 .6 & $25.7 \pm 3.1$ & 0.382 & 27.443 .3 & 23.332 .6 & $<0.001$ \\
\hline $\begin{array}{l}\text { Obesity, (n) } \\
\text { wasist cirumstance, } \mathrm{cm}\end{array}$ & $79(21.8)$ & $\begin{array}{l}77(22.1) \\
90.895\end{array}$ & $\begin{array}{l}2(2.5) \\
30377\end{array}$ & 0.392 & $73(39.0)$ & $\begin{array}{l}4(2.5) \\
050.772\end{array}$ & $<0.001$ \\
\hline $\begin{array}{l}\text { Waist cicrumstance, } \mathrm{cm} \\
\text { Metabolic syndrome, } \mathrm{n}(\%)\end{array}$ & $\begin{array}{l}90.859 .4 \\
1.55 / 4.66\end{array}$ & $\begin{array}{l}90.889 .5 \\
1.88(15.4)\end{array}$ & $\begin{array}{l}89.337 .4 \\
7(50.0\end{array}$ & 0.0 .751 & $95.9 \pm 8.3$ & 85.047.2 & $<0.001$ \\
\hline $\begin{array}{l}\text { Fatty liver, } n(\%) \\
\text { (\%) }\end{array}$ & $\begin{array}{l}172(47.5) \\
170.51\end{array}$ & $\begin{array}{l}165(47.4) \\
139(4)\end{array}$ & $7(50.0)$ & 0.849 & 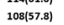 & $57(35.4)$ & $\begin{array}{l}<0.001 \\
<0.001\end{array}$ \\
\hline Coronary heart disease, $n(\%)$ & $3(2.2)$ & $6(1.7)$ & $2(14.3)$ & 0.027 & $1(0.5)$ & $5(3.1)$ & 0.100 \\
\hline $\mathrm{BF} \%, \%$ & $25.8 \pm 6.4$ & 25.5\$6.2 & 35.055 .0 & $<0.001$ & $30.1 \pm 3.8$ & $20.1+3.7$ & $<0.001$ \\
\hline Overfat, $n(\%)$ & 194453.6] & $187(53.7)$ & $7(50.0)$ & 0.733 & $187(100)$ & $0(0)$ & $<0.001$ \\
\hline Trunk BF\%,\% & 13.333 .7 & 13.133 .6 & 17.922 .8 & $<0.001$ & $15.8 \pm 1.9$ & $10.1+2.4$ & $<0.001$ \\
\hline Limb BF\%,\% & 11.03 .7 & 10.722 .8 & 18.1110.2 & 0.017 & $12.7 \pm 2.1$ & $8.4 \pm 1.5$ & $<0.001$ \\
\hline Trunk/Limb BF\%, ratio & 1.2220.15 & $1.22 \pm 0.14$ & 1.10t0.24 & & 1.25t0.11 & $1.19 \pm 0.17$ & $<0.001$ \\
\hline
\end{tabular}

Conclusion: The characteristics of fat distribution in male gout patients is more in trunk and trunk BF\% is positively correlated with sUA.

Disclosure of Interests: None declared

DOI: 10.1136/annrheumdis-2019-eular.5228

\section{SAT0416 ULTRASOUND EVALUATION IN FOLLOW-UP OF URATE-LOWERING THERAPY IN GOUT PHASE 2 (USEFUL-2): DURATION OF FLARE PROPHYLAXIS}

Esther Ebstein $^{1}{ }^{\text {, Marine Forien }}{ }^{1}$, Eleonora Norkuviene ${ }^{2}$, Pascal Richette ${ }^{3}$, Gael Mouterde $^{4}$, Claire Daien ${ }^{4}$, Hang Korng Ea ${ }^{3}$, Claire Brière ${ }^{3}$, Frederic Lioté ${ }^{3}$, Mykolas Petraitis ${ }^{2}$, Thomas Bardin ${ }^{3}$, Jeremy Ora ${ }^{3}$, Philippe Dieudé ${ }^{1}$, Sebastien Ottaviani ${ }^{1} .{ }^{1}$ Rheumatology Department, DHU FIRE, Pôle infection immunité, Bichat Hospital (APHP), Paris, France, Paris, France; ${ }^{2}$ Lithuanian University of Health Sciences, Kaunas, Rheumatology, Kaunas, Lithuania; ${ }^{3}$ centre Viggo Petersen, pole appareil locomoteur, Lariboisière Hospital (AP-HP); Inserm UMR 1132, USPC, Rheumatology, paris, France; ${ }^{4}$ Lapeyronie hospital, EA 2415 , Montpellier University, Rheumatology, Montpellier, France

Background: Recent studies showed that ultrasonography (US) could be useful for managing urate-lowering therapy (ULT) in gouty patients. In the first phase of the present study (USEFUL-1), we suggested that US was an accurate tool to follow monosodium urate (MSU) crystal dissolution under efficient ULT.

For gout flare after starting ULT, prophylaxis is recommended during the first 6 months of ULT. The duration of gout flare prophylaxis over the 6 months is consensual with a grade B recommendation. However, little is known about the probability of relapse according to the urate load modification.

Objectives: To determine whether a modification of US features of MSU crystal deposition is associated with reduced number of flares after stopping gout flare prophylaxis.

Methods: We performed a 1-year multicentre prospective study including patients with proven gout and US features of gout. The first phase of the study was a 6-month US follow-up after starting (ULT) with gout flare prophylaxis. After 6 months of ULT, gout flare prophylaxis was stopped, followed by a clinical follow-up (month [M] 6 to 12). Outcomes were the proportion of patients with relapse between M6 and M12 according to the modification of US features of gout and determining a threshold decrease in tophus size according to the probability of relapse.

Results: We included 79 patients with gout (mean [ \pm SD] age $61.8 \pm 14$ years, $91 \%$ males, disease duration $6.3 \pm 6.1$ years). Among the 49 completers at M12, 23 (47\%) experienced relapse. Decrease in tophus size $\geq 50 \%$ at $M 6$ was more frequent without than with relapse $(54 \%$ vs $26 \%, P=0.049$ ). On ROC curve analysis, a threshold decrease of $50.8 \%$ in tophus size had the best sensitivity/specificity ratio to predict relapse. Probability of relapse was increased for patients with a decrease in tophus size $<50 \%$ between baseline and M6 (OR 3.35 [95\% confidence interval 0.98; 11.44]).

Conclusion: A high reduction in US tophus size is associated with low probability of relapse after stopping gout prophylaxis. US follow-up may be useful for managing ULT and gout flare prophylaxis.

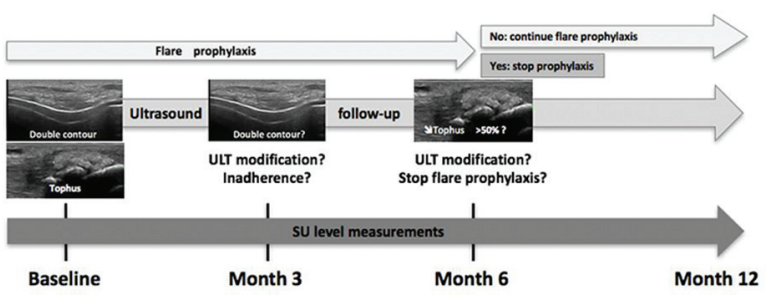

Disclosure of Interests: Esther Ebstein: None declared, Marine Forien None declared, Eleonora Norkuviene: None declared, Pascal Richette Consultant for: Grunenthal, Horizon, Speakers bureau: AstraZeneca, Grunenthal, Gael Mouterde: None declared, Claire Daien: None declared, Hang Korng Ea: None declared, Claire Brière: None declared, Frederic Lioté Grant/research support from: institutional grants from Grunenthal, Ipsen Pharma/Menarini, Novartis, SOBI for the European Crystal Network Workshops, Consultant for: Grunenthal, Novartis, Mykolas Petraitis: None declared, Thomas Bardin Consultant for: Astrazeneca, Grunenthal, Horizon, Novartis, Speakers bureau: Astella, AstraZeneca, Grunenthal., Jeremy Ora: None declared, Philippe Dieudé: None declared, Sebastien Ottaviani: None declared

DOI: 10.1136/annrheumdis-2019-eular.1219

\section{SAT0417 HOW EFFECTIVE IS GOUT EDUCATION PROGRAMME TO IMPROVE GOUT KNOWLEDGE AMONG PRIMARY CARE DOCTORS?}

Hazlyna Baharuddin ${ }^{1}$, Nur Aini Eddy Warman ${ }^{1 *}$, Habibah Mohd Yusoof ${ }^{2}$, Ing Soo Lau ${ }^{2}$, Shereen Suyin Ch'ng ${ }^{2}$, Mollyza Mohd Zain ${ }^{2} .{ }^{1}$ Universiti Teknologi MARA, Department of Medicine, Sungai Buloh, Malaysia; ${ }^{2}$ Hospital Selayang, Department of Medicine, Batu Caves, Malaysia

Background: Gout is a potentially curable disease with simple pharmacological treatment, although its management remained suboptimal. ${ }^{1,}{ }^{2} \mathrm{~A}$ disconnection between primary care doctors who treat gout most frequently, and rheumatologists who lead the development of gout management guidelines, is one of the challenges in managing gout in primary care. $^{3} \mathrm{~A}$ concerted effort is needed to improve the quality of care of patients with gout and this includes physician education. ${ }^{4}$

Objectives: To determine the effectiveness of gout educational programme in improving gout knowledge among primary care doctors.

Methods: A gout education programme consisted of five 20-minute presentations on gout (challenges in gout, principles of gout management, treat to target, disease burden and gout diet) and a session on case discussion of two gout cases was conducted for primary care doctors. Participants were invited to complete the same set of questions distributed before (pre-test) and after (post-test) the programme. A set of 10 true/false multiple choice questions (MCQ) based on a clinical scenario of a patient with gout was constructed and vetted by two rheumatologists. Comparison between the pre-test and post-test scores were analysed using paired t-test.

Results: Forty-four primary care doctors who attended gout educational programme, answered pre-test and post-tests and the scores are shown in Table 1. The scores for recall questions were higher than application questions.The mean scores for recall questions in post-test were significantly higher compared to pre-test $(4.35 \pm 0.73$ vs $3.51 \pm 0.47, \mathrm{p}<0.01)$ but not significant for application questions ( $2.91 \pm 0.71$ vs $2.79 \pm 0.62, p=0.56$ ) Less than half of participants obtained correct answers for 13 out of 50 options in the pre-test mainly in questions 2, 3, 4, 6 and 7. (Table 1) 